\title{
EFFECTIVE ENERGY MANAGEMENT IN Polyethylene Production
}

\author{
MineliC-Bogdanic, A. \& Budin, R.
}

Abstract: The energy management program is the important part of the satisfying any industrial production especially for energy process like low density polyethylene (LDPE) production. Therefore this study based on industrial polymerization process data proposed the option for energy saving applying flue gases heat recovery. Energy analysis shows the increase of process efficiency simultaneously the decrease of thermal pollution. Using an economizer (ECO) for boiler feed water preheating with flue gases heat, the natural gas consumption lowered for 10,7\%. At the same time the flue gases exhaust temperature diminished from $230^{\circ} \mathrm{C}$ to $47^{\circ} \mathrm{C}$. The presented analysis appears to be attractive for industrial users.

Key words: polymerization, LDPE, fuel consumption, heat recovery, savings
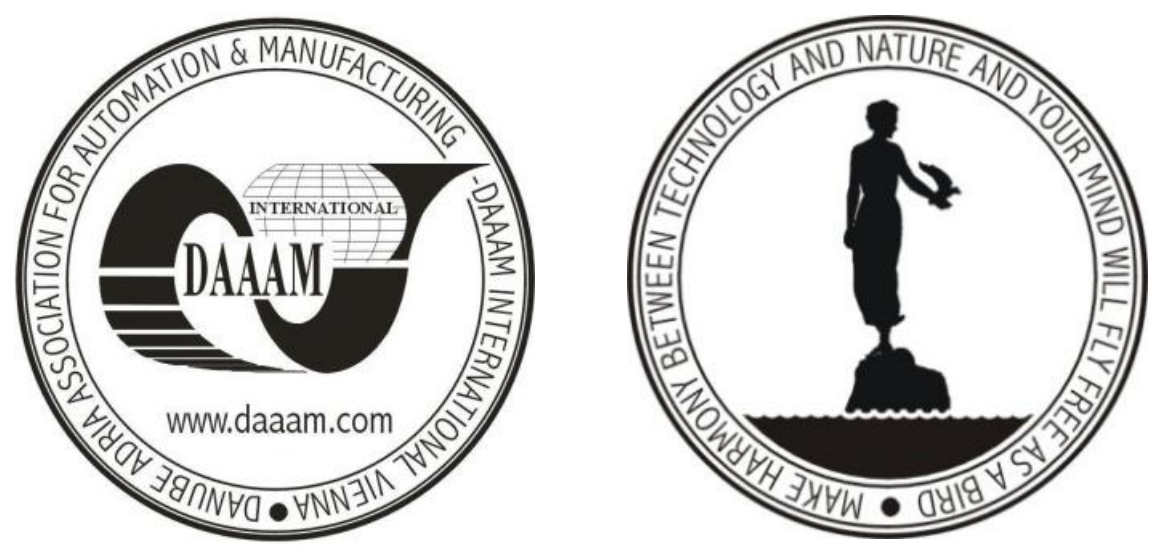

Authors' data: Univ.Prof. Dipl.-Ing. Dr.techn. Mihelic-Bogdanic, A[lka]*; Univ.Prof. Dipl.-Ing. Dr.techn. Budin, R[ajka]**, *Faculty of Textile Technology, University of Zagreb, Savska 16, 10000 Zagreb, Croatia, ** Faculty of Chemical Engineering and Technology, University of Zagreb, Savska 16, 10000 Zagreb, Croatia, amihel@fkit.hr, rbudin@fkit.hr

This Publication has to be referred as: Mihelic-Bogdanic, A[lka] \& Budin, R[ajka] (2011). Effective energy management in polyethylene production, Chapter $\mathrm{xx}$ in DAAAM International Scientific Book 2011, pp. 063-070, B. Katalinic (Ed.), Published by DAAAM International, ISBN 978-3-901509-84-1, ISSN 1726-9687, Vienna, Austria

DOI: $10.2507 /$ daaam.scibook.2011.05 


\section{Introduction}

Low density polyethylene (LDPE) is a part of polyolefin group which is made up of ethylene monomers connected together. This stable thermoplastic polymer is produced by low density high pressure polymerization of ethylene (Doak, et al., 2004). The monomer is composed from a petrochemical material or from alternative sources like syngas and biomass (Lopez, et al., 2006). Stabile thermoplastics polyethylene as a final product containing thousands of bound ethylene (Bergstra, 2004). LDPE characterize chemical resistance, high impact strength at low temperature, excellent electrical properties, high intrinsic thermal stability etc. (Rodriguez, 1996). Due to its unique properties low density polyethylene is used in critical applications where stress cracking resistance is an issue such as wire cable. Regarding a wide range of many desirable properties including water and chemical resistance, energy absorbance, buoyancy and cushioning characteristics, this thermoplastics material is an important commercial product. Because of excellent properties LDPE has numerous applications such as pharmaceutical packaging, electrical cable and paper board coating etc. (Stevens, 1999).

Because of significant amount of thermal energy LDPE production is one of the energy intensive processes in petrochemical industry. Therefore some conservation options are proposed and analyzed. The potential methods for improving energy efficiency considering actual industrial process (Production plant data, 2006) include relevant data, energy consumption and conservation possibilities as well as flue gases waste heat reusing. With regard to thermal energy consumption there is proposed and carried out option aimed to improvement measures.

At the present time the process great quantity of process hot condensate alike flue gases are rejected to the surrounding. Presented process optimization results with energy conservation and lowest wastes and therefore is environmentally friendly. One of the very common methods for fuel consumption decreasing i.e. fuel saving includes the applying of waste heat recovery. Namely, the high temperature of flue gases presents also an indicative capability for energy efficiency increasing (Thumann, 1989).

The investigation of the boiler exhaust flue gases providing for boiler water preheating in the economizer is presented here. The impact of the heat recovery on the development of energy conservation and environment protection is making known. This method has a marked influence on industrial energy consumption and environmental and economics advantage. Utilizing the heat of flue gases, fuel consumption, water pollution and the temperature of exhaust flue gases should be lowered.

Presented benefits based on detailed energy analyses include the actual industrial process data from the initial raw material to the final product.

\section{Technological process relevant data}

The necessary data collected through production process (Fig.1.) monitoring are used for the presenting optimization method (Production plant data, 2006). 


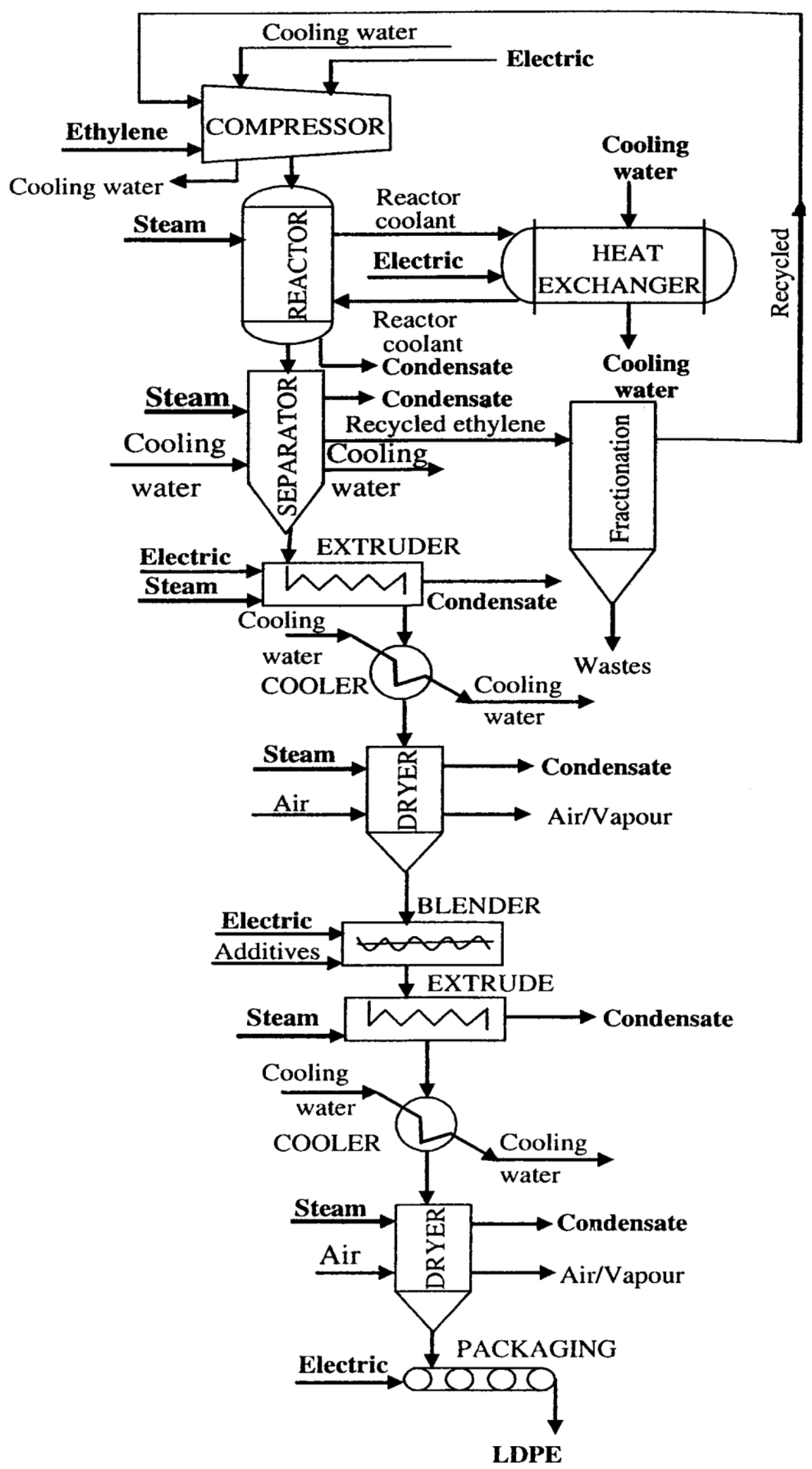

Fig. 1. Flow sheet of ethylene polymerization processes 
The process of ethylene polymerization consists of several unit operations that comprise the industrial polyethylene production (LDPE). The polymerization flow diagram (Fig.1.) shows relevant inlet and outlet streams with the electric and thermal energy for each of the unit operation (Cervantes et al., 2000). From the process configuration is visible that production technology consist of several energy consumption operations in following equipments: compressor, reactor, heat exchanger, separators, extruders, dryers, blender, packaging. This technology needs thermal and electrical energy as well as water. Electrical energy in amount of 9,8 $\mathrm{MW}_{\mathrm{e}}$ is supplied from the grid. Thermal energy in mass of 8,7 $\mathrm{MW}_{\mathrm{t}}$ is produced in a stem generator.

\section{Basic process calculation}

The evaluation of process energy is curried out using relevant production data. The required thermal energy is produced in a natural gas fueled boiler with efficiency $\eta_{\mathrm{B}}=85 \%$. The natural gas is burned with $20 \%$ excess air i.e. combustion air excess coefficient $\alpha=20 \%$. From the fuel volumetric analysis:

$$
\mathrm{CH}_{4}: \mathrm{C}_{2} \mathrm{H}_{6}: \mathrm{C}_{3} \mathrm{H}_{8}: \mathrm{C}_{4} \mathrm{H}_{10}: \mathrm{C}_{5} \mathrm{H}_{12}: \mathrm{CO}_{2}: \mathrm{N}_{2}=98,05: 0,36: 0,12: 0,05: 0,01: 0,85: 0,56 \text {, }
$$

the lower heating value $\mathrm{H}_{\mathrm{L}}\left(\mathrm{kJ} / \mathrm{m}^{3}\right)$ is calculated using following equation (Pozar,1992):

what gives:

$$
\mathrm{H}_{\mathrm{L}}=358 \mathrm{CH}_{4}+636 \mathrm{C}_{2} \mathrm{H}_{6}+913 \mathrm{C}_{3} \mathrm{H}_{8}+1158 \mathrm{C}_{4} \mathrm{H}_{10}+1465 \mathrm{C}_{5} \mathrm{H}_{12}
$$

$$
\mathrm{H}_{\mathrm{L}}=35507 \mathrm{~kJ} / \mathrm{m}^{3} \text { fuel. }
$$

The existing plant includes a boiler generating superheating steam at 6 bar, $254^{0} \mathrm{C}$. After steam passes through the production process saturated liquid is rejected to the surrounding. The plant use factor is $\beta=75 \%$ what gives operating time of $\tau=6570 \mathrm{~h}$ per year. Water enters the boiler with $\mathrm{t}_{\mathrm{B}}=20^{\circ} \mathrm{C}$.

Steam mass rate $D_{S}(\mathrm{~kg} / \mathrm{h})$ is calculated from process thermal energy needs $\mathrm{N}_{\mathrm{t}}=8,7 \mathrm{MW}_{\mathrm{t}}$ what gives heat in amount of $\mathrm{Q}_{\mathrm{t}}=31,3 * 10^{6} \mathrm{~kJ} / \mathrm{h}$ as follows:

$$
\begin{gathered}
\mathrm{D}_{\mathrm{S}}\left(\mathrm{h}_{\mathrm{S}}-\mathrm{h}_{\mathrm{B}}\right)=\mathrm{Q}_{\mathrm{t}} \\
\mathrm{D}_{\mathrm{S}}=\mathrm{Q}_{\mathrm{t}} /\left(\mathrm{h}_{\mathrm{S}}-\mathrm{h}_{\mathrm{B}}\right)=31,3 * 10^{6} /(3031-83,7)=10,6 * 10^{3} \mathrm{~kg} / \mathrm{h} .
\end{gathered}
$$

The enthalpy of superheating steam $h_{S}=3031 \mathrm{~kJ} / \mathrm{kg}$ and for saturated liquid $\mathrm{h}_{\mathrm{B}}=83,7 \mathrm{~kJ} / \mathrm{kg}$ are taken from (Budin, \& Mihelic-Bogdanic, 2002).

The natural gas input $V_{F}\left(\mathrm{~m}^{3} / \mathrm{h}\right)$ is:

$$
\begin{gathered}
\mathrm{V}_{\mathrm{F}}=\mathrm{Q}_{\mathrm{t}} /\left(\mathrm{H}_{\mathrm{L}} * \eta_{\mathrm{B}}\right) \\
\mathrm{V}_{\mathrm{F}}=31,3 * 10^{6} /(35507 * 0,85)=1037 \mathrm{~m}^{3} / \mathrm{h} .
\end{gathered}
$$

With plant use factor $\beta=75 \%$ i.e. $\tau=6570 \mathrm{~h}$ per year natural gas consumption is 


$$
\begin{aligned}
& \mathrm{V}_{\mathrm{FY}}=\mathrm{V}_{\mathrm{F}} * \tau \\
& \mathrm{V}_{\mathrm{FY}}=1037 * 6570=6,8 * 10^{6} \mathrm{~m}^{3} / \text { yearly. }
\end{aligned}
$$

The yearly thermal energy supply expressed in terms of coal equivalent (tCE):

$$
\begin{gathered}
\mathrm{tCE}_{\mathrm{t}}=\left(\mathrm{Q}_{\mathrm{t}} * \tau\right) / \mathrm{H}_{\mathrm{CE}} \\
\mathrm{tCE}_{\mathrm{t}}=\left(31,3 * 10^{6} * 6570\right) / 29,3 * 10^{6}=7018,5
\end{gathered}
$$

The coal equivalent heating value from (Pozar, 1992)

$$
\mathrm{tH}_{\mathrm{CE}}=29,3 * 10^{6} \mathrm{~kJ} \text { of } 1 \text { ton coal equivalent. }
$$

\section{Boiler feed water preheating with flue gases}

The ethylene polymerization is one of the energy intensive process (Sutlovic et al., 2004) in petrochemical industry which results with low density polyethylene (LDPE) production (Encyclopedia of Energy, 2004). Here presented energy analysis shows that production process efficiency increasing if the boiler flue gases are returned to the process (Turner \& Doty, 2006).

One of the possibilities of the flue gases heat recovery is applying for boiler feed water preheating using heat exchanger i.e. economizer (ECO) (MihelicBogdanic \& Budin, 2002).

Another option for stack reusing is the combustion air preheating in an air preheater before entering the boiler (Eastop\&Croft, 1995, Kreith\&West, 1997). Because of satisfying flue gasses temperature after leaving ECO i.e. feed water preheating the gasses are using for combustion air preheating.

The combination of both before described options shows a significant energy and ecological advantage what is visible from fuel savings as well as flue gases outlet temperature reducing.

The next method for efficiency improvement is process condensate heat reusing (Mihelic-Bogdanic \& Budin, 2008). Returning condensate to the boiler the amount of fuel could be reduced 10-30\% (Budin, at al., 1999). This option results also with ecological superiority declared as reduced water pollution. This valuable conservation also saves energy and chemicals applied for boiler water treating (Kreith\&West, 1997).

Considering energy requirement of LDPE production in presented study the possibility of process efficiency improvement is make known by analysing industrial process with boiler feed water preheating. Reusing flue gases heat for water preheating in ECO before entering boiler has a significant potential for energy conservation (Energy technologies, 1997).

The flue gases heat is used in economizer (ECO) for boiler feed water preheating. The calculation procedure for proposed process takes into consideration before mentioned fuel composition and requirement $\mathrm{V}_{\mathrm{F}}=1037 \mathrm{~m}^{3} / \mathrm{h}$. 
Now, the stoichiometric volume of combustion air (Potter \& Somerton, 1993) is estimated from following equation:

$$
\mathrm{V}_{\mathrm{a}}=\left[\Sigma \mathrm{r}_{\mathrm{m}}(\mathrm{x}+\mathrm{y} / 4)\right] / 21=9,5 \mathrm{~m}_{\mathrm{a}}^{3} \mathrm{~m}_{\mathrm{F}}^{3}
$$

where: $\mathrm{r}_{\mathrm{m}}=$ volume part of each fuel constituent (\%), $\mathrm{x}, \mathrm{y}$ number of $\mathrm{C}$ and $\mathrm{H}$ atoms respectively in each fuel constituent.

With before mentioned combustion air excess coefficient $\alpha=20 \%$, the actual combustion air volume becomes:

$$
\mathrm{V}_{\mathrm{a} \alpha}=\mathrm{V}_{\mathrm{a}} * \alpha=9,5 * 1,2=11,4 \mathrm{~m}_{\mathrm{a}}^{3} / \mathrm{m}_{\mathrm{F}}^{3}
$$

The total volume of flue gases which consists of $\mathrm{CO}_{2}, \mathrm{H}_{2} \mathrm{O}, \mathrm{N}_{2}$ and $\mathrm{O}_{2}$ is:

$$
\begin{aligned}
& \mathrm{V}_{\mathrm{FG}}=\mathrm{V}_{\mathrm{CO}_{2}}+\mathrm{V}_{\mathrm{H}_{2} \mathrm{O}}+\mathrm{V}_{\mathrm{N}_{2}}+\mathrm{V}_{\mathrm{O}_{2}}= \\
& 0,01\left(\mathrm{CO}_{2}+\Sigma \mathrm{XC}_{\mathrm{X}} \mathrm{H}_{\mathrm{Y}}+0,5 \Sigma \mathrm{YC}_{\mathrm{X}} \mathrm{H}_{\mathrm{Y}}+\mathrm{V}_{\mathrm{a}}(\alpha-1) \mathrm{d} / \rho+\alpha\left(0,79 \mathrm{~V}_{\mathrm{a}}+0,8 \mathrm{~N} / 100\right)+0,21(\alpha-1) \mathrm{V}_{\mathrm{a}}=\right. \\
& =12,4 \mathrm{~m}_{\mathrm{FG}}^{3} / \mathrm{m}_{\mathrm{F}}^{3}
\end{aligned}
$$

while $\mathrm{d}=13 \mathrm{~g} / \mathrm{m}^{3}$ is water vapor content in air and $\rho=0,805 \mathrm{~kg} / \mathrm{m}^{3}$ is density of water vapor in air.

The volume of the flue gases in an inefficient process expressed in $\mathrm{m}^{3}{ }_{\mathrm{FG}} / \mathrm{h}$ is:

$$
\mathrm{V}_{\mathrm{FGh}}=\mathrm{V}_{\mathrm{FG}} * \mathrm{~V}_{\mathrm{F}}=12,4 * 1037=13066 \mathrm{~m}_{\mathrm{FG}}^{3} / \mathrm{h} \text {. }
$$

In this conventional process without any optimization the flue gases are rejected to the atmosphere with temperature $\mathrm{t}_{\mathrm{FG}}=230^{\circ} \mathrm{C}$.

In order to improve the process efficiency as before proposed, the flue gases heat could be reused in an economizer (Fig.2.) with efficiency of $\eta_{\mathrm{ECO}}=86 \%$.

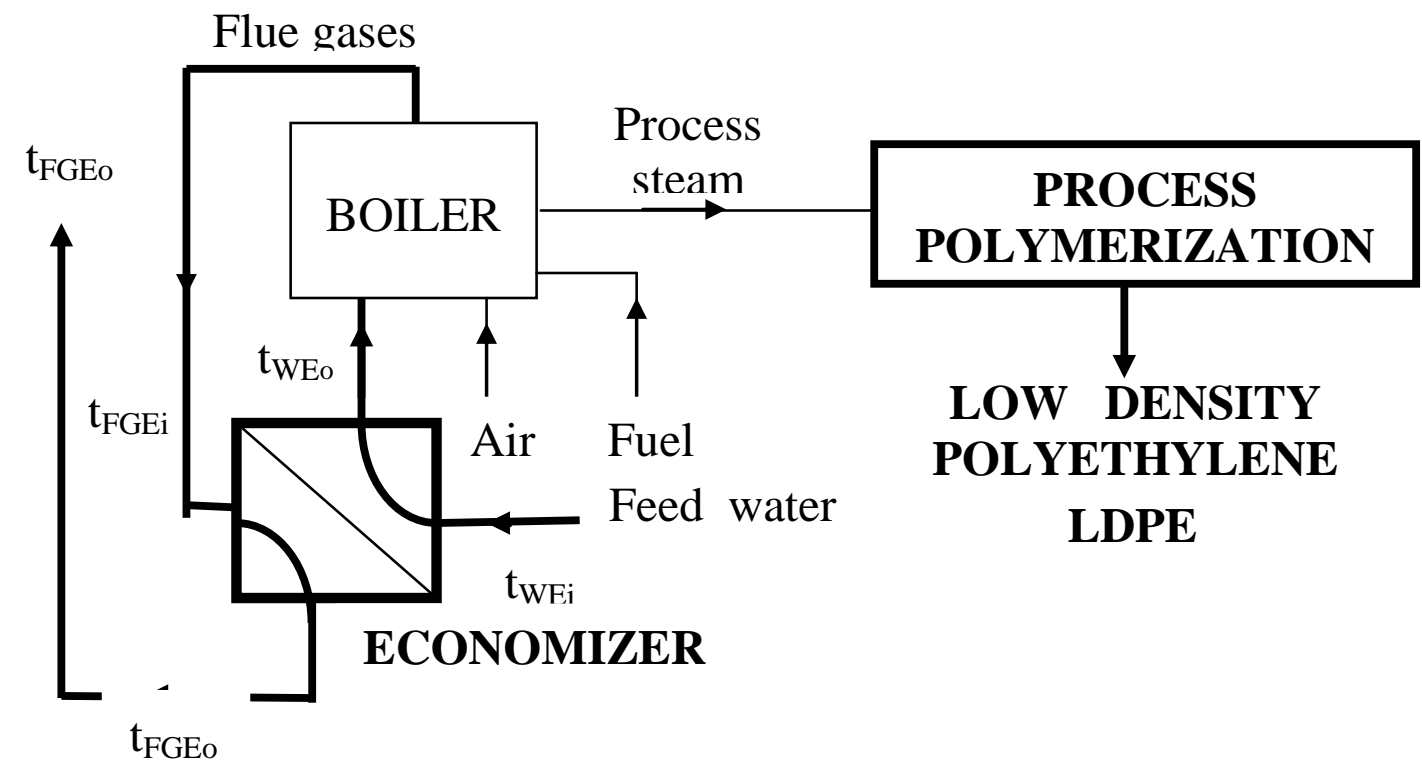

Fig. 2. Process with flue gasses heat recovery 
Boiler feed water enters ECO with $t_{\mathrm{WEi}}=\mathrm{t}_{\mathrm{B}}=20^{\circ} \mathrm{C}$. The flue gases with temperature $\mathrm{t}_{\mathrm{FGEi}}=230^{\circ} \mathrm{C}$ passed through $\mathrm{ECO}$ where feed water is preheating before entering the boiler. The flue gases outlet temperature $\mathbf{t}_{\mathbf{F G E o}}$ and economizer water outlet temperature $\mathbf{t}_{\mathbf{W E o}}$ i.e. steam boiler inlet temperatures are calculated from the following balance:

$$
\mathrm{D}_{\mathrm{S}} * \mathrm{c}_{\mathrm{pH}} \mathrm{O}\left(\mathbf{t}_{\mathrm{WEo}}-\mathrm{t}_{\mathrm{WEi}}\right)=\mathrm{V}_{\mathrm{FG}} * \mathrm{c}_{\mathrm{pFG}}\left(\mathrm{t}_{\mathrm{FGEi}}-\mathrm{t}_{\mathrm{WEi}}\right) \eta_{\mathrm{ECO}}=\mathrm{V}_{\mathrm{FG}} * \mathrm{c}_{\mathrm{pFG}}\left(\mathrm{t}_{\mathrm{FGEi}}-\mathbf{t}_{\mathrm{FGEo}}\right)
$$

where $\mathrm{c}_{\mathrm{pH}_{2} \mathrm{O}}=4,187 \mathrm{~kJ} / \mathrm{kg} \operatorname{grad}, \mathrm{c}_{\mathrm{pFG}}=1,382 \mathrm{~kJ} / \mathrm{m}^{3}$ grad are the water and flue gases specific heat. From equation (10) the boiler feed water temperature $\mathbf{t}_{\mathbf{W E}}=\mathbf{9 4}, \mathbf{4}^{\mathbf{0}} \mathrm{C}$ while flue gases outlet temperature $\mathbf{t}_{\mathbf{F G E}}=\mathbf{4 7 ^ { 0 }} \mathrm{C}$.

Using balance (10) flue gases heat $\mathrm{Q}_{\mathrm{FGE}}(\mathrm{kJ} / \mathrm{h})$ is:

$$
\mathrm{Q}_{\mathrm{FGE}}=\mathrm{V}_{\mathrm{FG}} * \mathrm{c}_{\mathrm{pFG}}\left(\mathrm{t}_{\mathrm{FGEi}}-\mathrm{t}_{\mathrm{WEi}}\right) \eta_{\mathrm{ECO}}=13066 * 1,382(230-20) * 0,86=3,3 * 10^{6} \mathrm{~kJ} / \mathrm{h} \text {. }
$$

The volume of natural gas in process for feed water preheating with flue gases in $\mathrm{ECO}$ is:

$$
\mathrm{V}_{\mathrm{FECO}}=\mathrm{D}_{\mathrm{S}}\left(\mathrm{h}_{\mathrm{S}}-\mathrm{h}_{\mathrm{WEo}}\right) / \mathrm{H}_{\mathrm{L}} * \eta_{\mathrm{B}}=10,6 * 10^{3}(3031-395) / 35507 * 0,85=925,8 \mathrm{~m}^{3} / \mathrm{h} .
$$

Comparison with the process without flue gases heat recovery shows natural gas savings of:

$$
\mathrm{S}=\mathrm{V}_{\mathrm{F}}-\mathrm{V}_{\mathrm{FECO}} / \mathrm{V}_{\mathrm{F}}=1037-925,8=0,107=10,7 \% \text {. }
$$

\section{Conclusion}

A heat recovery system which uses the waste exhaust heat from boiler flue gases has proved to be very efficient. Considering the potential possibility for heat energy savings the boiler feed water preheating with flue gases is proposed. Therefore gaseous fuel requirements for the energy intensive ethylene polymerization which results with low density polyethylene LDPE is analyzed.

The presented proposed method for boiler feed water preheating using economizer, which is simply gas to liquid water heating devices, shows that the process efficiency is still increasing. Based on presented industrial process, the applying flue gases heat recovery results with natural gas savings of $10,7 \%$. Except energy and economy, the process has also ecology benefits visible from the flue gases outlet temperature lowering. In the conventional process the flue gases exhaust temperature is $230^{\circ} \mathrm{C}$, while in an optimizing process becomes $47^{\circ} \mathrm{C}$.

\section{References}

Bergstra, M. F. (2004). Catalytic Ethylene Polymerization, Bergstra, ISBN 90-3652091-6, Enschede, The Netherlands

Budin, R. \& Mihelic-Bogdanic, A. (2002). Fundamentals of Technical Thermodynamics (in Croatian), Školska knjiga, ISBN 953-0-31688-7, Zagreb 
Budin,R.;Sutlovic,I. \& Barjaktarevic,Z. (1999). Heat recovery in dying process with reactive dyes, Proceedings of the $4^{\text {th }}$ International Conference on New Energy Systems and Conversions, T. Ohta et al., (Ed.), pp. 175-177, ISBN 4-9980752$1-7$

Cervantes,A., Tonelli S., Brandolin, A.,Bandoni,A. \& Biegler, L. (2000). Large scale dynamic optimization of a law density polyethylene plant. Computer and Chemical Engineering, Vol.24., No,2-7., (2000),pp.983-989, ISSN 0098-1354

Doak, K. W., James, D.E. \& Kisin, Y.V. (2004). Ethylene Polymers, in Encyclopedia of Polymer Science and Engineering, 3th Edition., Vol.6, John Wiley\&Sons, ISBN-10: 047 1275077, New York

Eastop, T. D. \& Croft, D. R. (1995). Energy Efficiency, Longman Group Ltd, ISBN 0-582-03184-2, Essex

Encyclopedia of Energy, Vol.1 (2004). Cleveland, C.J. (Ed.), Elsevier, Academic Press, ISBN 0-12-176481-8, San Diego

Encyclopedia of Energy, Vol.1 (2004). Cleveland, C.J. (Ed.), Elsevier, Academic Press, ISBN 0-12-176481-8, San Diego

Energy technologies for the 21 st century. (1997). OECD/IEA, Paris

Kreith,F. \& West,R.E. (1997). Energy Efficiency, CRC Press, ISBN 0-8493-2514-5, New York

Lopez, A., Pedraza, J.J. \& Del Almo, B. (1996). Industrial application of a simulation model for high pressure polymerization of ethylene. Computer and Chemical Engineering, Vol.20., No.12., (Supplement 2), (1996),pp.1625-1630, ISSN 0098-1354

Mihelic-Bogdanic,A. \& Budin,R. (2002). Heat recovery in thermoplastics production.Energy Conversion and Management,Vol. 43., No. 8., (2002), pp.1079-1089, ISSN 0196-8904

Mihelic-Bogdanic,A. \& Budin,R. (2008). Investigation on energy conservation in thermoplastics production. Energy Conversion and Management, Vol. 49., No. 8., (2008), pp.2200-2206, ISSN 0196-8904

Potter, M. C. \& Somerton, C. W. (1993). Scham's outline of theory and problem of engineering thermodynamics, McGrow-Hill.INC., ISBN 0-07-050616-7, New York

Pozar, H. (1992). Fundamentals of Energetic (in Croatian), Skolska knjiga, ISBN 8603-00165-0, Zagreb

Production plant data. Private communication, 2004. Zagreb

Rodriguez, F. (1996). Principles of polymer systems, Taylor \& Frances, ISBN 1560323256, Washington

Stevens, M.P. (1999). Polymer chemistry, Oxford University Press, ISBN 0195124448, Oxford

Sutlovic,I., Budin, R. \& Mihelic-Bogdanc, A.(2004). Enrgy evaluation of the polymerization process. Sigurnost,Vol. 46., No. 2., (2004), pp.97-108, ISSN 0350-6886

Thumann, A. (1989). Plant Engineers and Managers, Guide to Energy Conservation.Lilburn: The Fairmont Press Inc., ISBN 0-88173-093-9, Lilburn

Turner, W.C. \& Doty, S. (2006). Energy management handbook, Sixth Edition, The Fairmont Press, Inc.,ISBN 0-88173-542-6,Lilburn 